\title{
The Middle Jurassic of western and northern Europe: its subdivisions, geochronology and correlations
}

\author{
John H. Callomon
}

The palaeogeographic settings of Denmark and East Greenland during the Middle Jurassic are outlined. They lay in the widespread epicontinental seas that covered much of Europe in the post-Triassic transgression. It was a period of continuing eustatic sea-level rise, with only distant connections to world oceans: to the Pacific, via the narrow Viking Straits between Greenland and Norway and hence the arctic Boreal Sea to the north; and to the subtropical Tethys, via some $1200 \mathrm{~km}$ of shelf-seas to the south.

The sedimentary history of the region was strongly influenced by two factors: tectonism and climate. Two modes of tectonic movement governed basinal evolution: crustal extension leading to subsidence through rifting, such as in the Viking and Central Grabens of the North Sea; and subcrustal thermal upwelling, leading to domal uplift and the partition of marine basins through emergent physical barriers, as exemplified by the Central North Sea Dome with its associated volcanics. The climatic gradient across the $30^{\circ}$ of temperate latitude spanned by the European seas governed biotic diversity and biogeography, finding expression in rock-forming biogenic carbonates that dominate sediments in the south and give way to largely siliciclastic sediments in the north.

Geochronology of unrivalled finesse is provided by standard chronostratigraphy based on the biostratigraphy of ammonites. The Middle Jurassic saw the onset of considerable bioprovincial endemisms in these guide-fossils, making it necessary to construct parallel standard zonations for Boreal, Subboreal or NW European and Submediterranean Provinces, of which the NW European zonation provides the primary international standard. The current versions of these zonations are presented and reviewed.

Keywords: Northwest Europe, North Sea, East Greenland, Middle Jurassic, palaeogeography, geochronology, ammonite biostratigraphy, standard chronostratigraphy

University College London, 20 Gordon Street, London WC1H OAJ, UK. E-mail: jobncallomon@lineone.net

Middle Jurassic sediments occur in almost all parts of what is conventionally drawn as the present-day continent of Europe - from Portugal to the Caucasus, Sicily to Svalbard, the Hebrides to the Petshora - but in the context of the present book, we shall confine ourselves essentially to western and northern Europe, broadly from the Alps to the Arctic (Fig. 1). The shelf-seas of the Barents Shelf and Svalbard, also still part of Europe today, are not included, but the eastern shores of Greenland are. The palaeolatitudes in the Middle Jurassic were about $15^{\circ}$ lower than they are today, so that Europe straddled the temperate zones from the sub-tropical to the sub-arctic. This is fully reflected both in the lithoand biofacies of the sediments, ranging from the predominantly warm-water carbonates in the south, with their immensely diverse fossil biotas, to the siliciclastics with their impoverished fossil assemblages in the north.

Historically, western Europe, as the cradle of geological science together with its superbly developed Jurassic successions, has given us a longstanding knowl- 


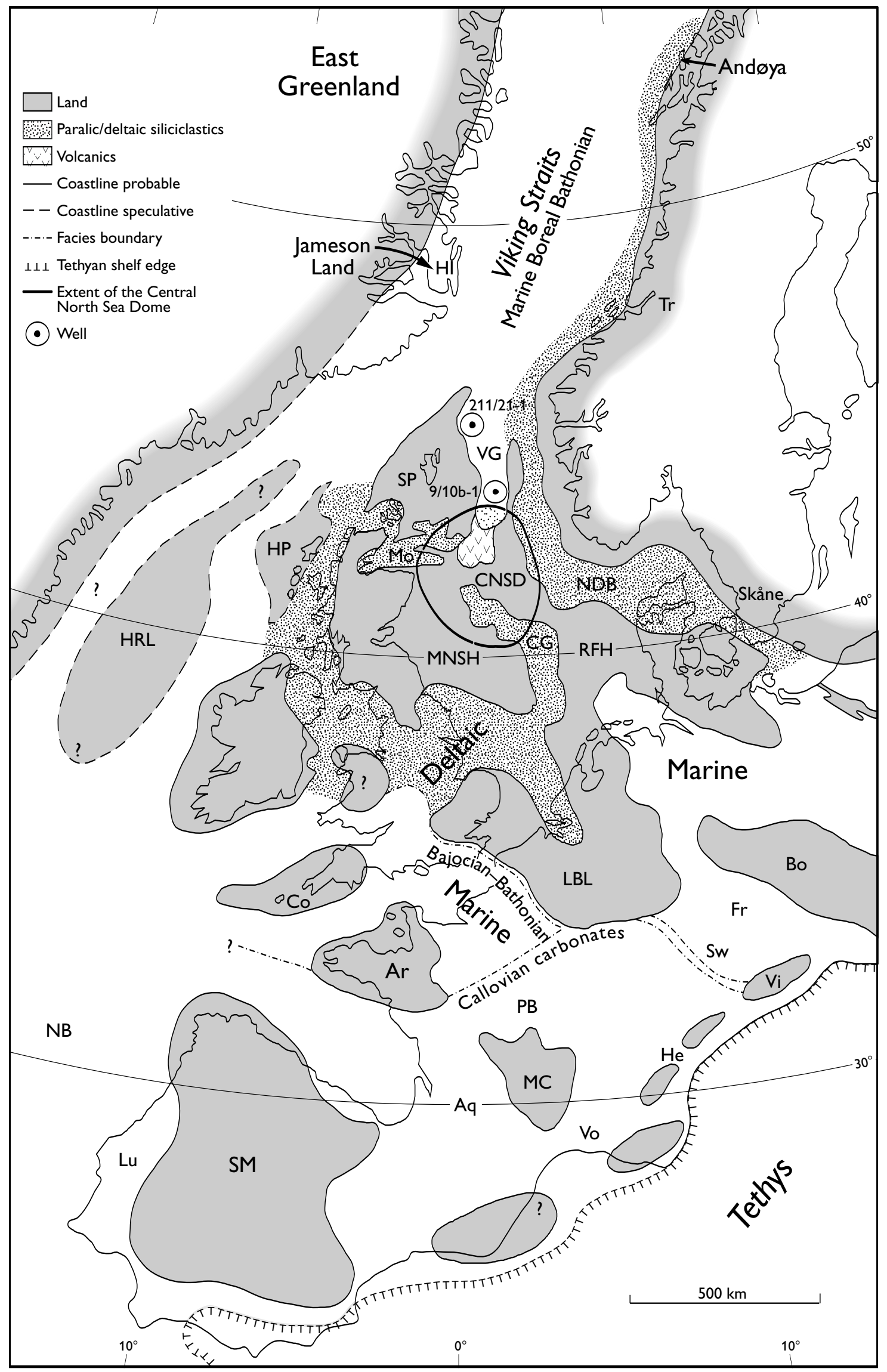


edge of that System unrivalled in detail. This is particularly the case in the Middle Jurassic. It provides the primary standard for comparisons with the rest of the world. To this Denmark has contributed little, for its Jurassic lies almost wholly in the subsurface.

More recently, the post-war quest for petroleum has opened up what had largely been an immense geological terra incognita, the circum-global Arctic. It quickly became apparent that the Middle Jurassic of the Arctic could not be simply correlated with that of western Europe because of non-overlapping endemisms in the distributions of the critical geochronometers, here the ammonites as guide-fossils. But at the same time, Danish geological expeditions to East Greenland revealed the key to correlations through the presence there of a residual sedimentary and biostratigraphical record so good that it has in turn become the chronostratigraphical standard for the whole of the Arctic. This gives the Jurassic of East Greenland an importance out of all proportion to the modest extent of its outcrops.

The Middle Jurassic makes also an important contribution to another area of more recent geological exploration. It is that of the former shelf-seas whose sediments now lie under the North Sea and along the margins of the southern North Atlantic, and whose interplay of tectonics and patterns of sedimentation form the major topics in other papers of the present volume. Here, Denmark does play a significant role by virtue of its position between the centres of active rifting in the North Sea and the passive littoral margins of the Baltic craton. The role of East Greenland is twofold. Firstly, it offers unique opportunities for direct study of fine examples, now splendidly exhumed onshore, of the kind of structures and basin-fills widespread in the sub-

\section{Facing page:}

Fig. 1. The palaeogeography of western Europe in the Middle Jurassic in early-mid Bathonian times. The dot-dashed lines south of $\mathrm{Ar}-\mathrm{LBL}$ represent the approximate northerly limits of dominantly carbonate lithologies. The channel shown between Greenland and the Hatton-Rockall Landmass (the East Greenland Rift of Ziegler 1982) is highly conjectural. Aq, Aquitaine Basin; Ar, Armorica; Bo, Bohemia; CNSD, Central North Sea Dome; Co, Cornubia; Fr, Franconia; He, Helvetic highs (Aar, Gothard, Mt. Blanc massifs); HI, Hurry Inlet; HP, Hebridean Platform; HRL, Hatton-Rockall Landmass; LBL, LondonBrabant Landmass; Lu, Lusitanian basins; MC, Massif Central; MNSH, Mid North Sea High; Mo, Moray Firth basin; NB, Newfoundland Banks; PB, Paris Basin; RFH, Ringkøbing-Fyn High; SM, Spanish Meseta; SP, Shetland Platform; Sw, Swabia; Tr, Trondheim Fjord; VG, Viking Graben; Vi, Vindelicia; Vo, Vocontian Trough. surface of the North Sea, important in the search for petroleum but necessarily mapped largely by indirect geophysical methods. Secondly, the biostratigraphy of its ammonites provides the most precise available timecontrol on the genetic sedimentology and basin analysis, at a level of time-resolution that can significantly steer the interpretations. This chronostratigraphy is outlined here in some detail.

\section{Palaeogeography, sedimentary basins and tectonics}

The Middle Jurassic experienced a continuing first-order worldwide (eustatic) rise in average sea level, reflected in the transgressive sediments still preserved on almost all of the surviving palaeocratonic, peri-oceanic margins of the former supercontinent Pangea. Taking the most optimistic estimate (see, for example, discussion by Hallam 1988) of, say, $+200 \mathrm{~m}$ for the Jurassic as a whole, this would suggest a mean value in the region of 50-100 $\mathrm{m}$ for thicknesses of epicontinental marine Middle Jurassic sediments that could be ascribed to eustatically-created accommodation space. One of the most plausible direct estimates to date (Sahagian et al. 1996), based on the truly cratonic Russian Platform, gives about $30 \mathrm{~m}$ for the Bajocian-Callovian inclusive. Whatever the meaning of such a figure might be generally, it does provide a yardstick when trying to estimate, or derive, the relative importance of the shorter-period, higher-order processes that modulate almost all sedimentary successions more locally. This includes the relative importance of higher-order eustatic fluctuations and regional tectonics in particular.

Palaeogeographically, the region around Denmark during the Jurassic lay still firmly inland on the Laurentian craton (Fig. 1). The landscape was one of gently undulating post-Caledonian and post-Hercynian topography whose highs had been eroded during the Carboniferous and Permian and whose lows had accumulated shallow marine evaporites and lacustrine or fluviatile continental sediments during the Triassic, a period of historically low worldwide sea level. The marine transgressions marking the onset of a new major cycle of eustatic sea-level rise at the beginning of the Jurassic then flooded a vast peneplain and inaugurated the regime of very extensive, shallow epicontinental seas so characteristic of the Jurassic and Cretaceous, far distant from the oceans and having few, if any, close current analogues. To the east lay the Eurasian continent, almost as large as it is today. To the north lay Fen- 
noscandia, firmly emergent during the whole of the Jurassic. To the west lay the shallow seas covering the North Sea, the British Isles and what are now the continental shelves of the North Atlantic, with the North American continent as far as Idaho and British Columbia beyond. To the south lay the shallow basins of the European platform, such the Anglo-Parisian, Aquitanian, Keltiberian, Rhodano-Helvetic, Franco-Swabian, Lower Saxonian and Polish Basins. The nearest ocean was the Tethys, $1200 \mathrm{~km}$ to the south. Access to it was not unrestricted but open through several broad channels. The only other access to the world's oceans was northwards, through the Viking Straits, another broad seaway lying between Fennoscandian Norway and Laurentian Greenland (not the Viking Graben, a tectonic entity), connecting the central European seas with those of the Arctic and thence the Pacific.

A number of residual Hercynian rumps persisted as basin highs or even islands during the Middle Jurassic. They include the Anglo-Brabant landmass ('LondonArdennes Island'), the Scottish Highlands, Cornubia, Armorica, the Massif Central, the Harz (Hercynia), Bohemia and Silesia. None of these were large or high enough to be major passive sources of primary coarse siliciclastic sediment, and although transgressive Middle Jurassic shoreline deposits may be observed at various places on them, the extent of their proximal facies is usually rather local. The largest source of both coarse and fine siliciclastics must have been the Scandinavian crystalline massifs to the north and east and, in the Viking Straits, also Greenland. The coarser sediments now occupy much of the shelves of the North Atlantic and a broad belt extending from the northern North Sea over Denmark into the Baltic. The finer sediments were very widely dispersed and the predominant facies of the European Middle Jurassic - the Brown Jura - north of the carbonate belts are clays, silts and fine-grained sands. Supply in most cases kept up with demand and even in troughs created by local subsidence (see below), water depths stayed more or less constant. The epicontinental European seas were shallow, perhaps in the range $0-100 \mathrm{~m}$, and quite small oscillations of relative sea level could produce transgressions and regressions over great distances. The positions of former shorelines are therefore often more than usually elusive.

This general first-order picture was however widely disrupted by tectonic movements. The break-up of Pangea had commenced and by the Middle Jurassic, Gondwana had parted from Laurasia. The North Atlantic remained closed, but the Central Atlantic had opened and West Africa was now separated from Appalachian America by
$1000 \mathrm{~km}$ of ocean. The effects of these major continental movements were clearly not localised in the Tethys but felt also further north. One widespread expression was in the form of rifting into horst and graben or halfgraben structures. Thus, the Vocontian Trough in southern France contains up to $750 \mathrm{~m}$ of Middle Jurassic sediments (Terres noires); the Lusitanian Basin off western Portugal up to $700 \mathrm{~m}$; the Central Graben of the North Sea, up to $1000 \mathrm{~m}$; the Viking Graben of the northern North Sea, up to $250 \mathrm{~m}$; and the basins of the Viking Straits whose fill is now preserved onshore in East Greenland, up to $700 \mathrm{~m}$. These were correlated major perturbations extending over $2000 \mathrm{~km}$ on a single plate.

Extensional rifting was complemented by other perturbations of a different character: a transient regional uplift centred in the Central North Sea (Ziegler 1982), driven by thermal upwelling of a subcrustal plume and followed by its dissipation and subsidence. The history of this event has been recently described in considerable detail by Underhill \& Partington (1993, 1994). The rise of the dome began in the late Early Jurassic (Toarcian). It broke marine surface in the Aalenian with the onset of erosion, providing a new source of sediment for its surrounding basins. It culminated with the effusion at its centre of a thick lava pile up to $1500 \mathrm{~m}$ thick, probably during the Bathonian-Callovian. Formerly termed the Rattray Formation (Deegan \& Scull 1977), these Middle Jurassic volcanics have been redefined as the Rattray Volcanics Member and the Ron Volcanics Member, both of the Pentland Formation (Richards et al. 1993). Deflationary subsidence with erosional peneplanation was substantially complete in the Late Oxfordian and was followed by marine transgression. The differential uplift of the central dome is estimated to have been (at least) 400-500 m. The whole cycle of topographic uplift and subsidence had a period of $40 \mathrm{Ma}$, but its highest point lay in the Middle Jurassic. Its palaeogeographic effects extended over an area more than $1200 \mathrm{~km}$ across, from the East Shetland Platform in the north to the Scottish Highlands and Yorkshire in the west, to the London-Brabant Massif in the south and the Ringkøbing-Fyn High in the east and taking in the Mid North Sea High - covering in fact almost the whole of the North Sea. Movements were more likely to have been pulsed than steady, both of doming and of rifting. Their sedimentary expressions could therefore well have been at least partly time-correlated across the region and given rise to widely recognisable successions of sequences and systems tracts. But with such a strong tectonic overprint, both of doming and of rifting, claims to be able successfully to identify an 
underlying higher-order eustatic cyclicity in the Middle Jurassic of the North Sea seem somewhat improbable.

\section{Palaeolatitude, climatology and bioprovincialism}

The shelf-seas of the European Middle Jurassic ranged in latitudes from about palaeolatitude $28^{\circ} \mathrm{N}$ (henceforth abbreviated to $\mathrm{p}-48^{\circ}$ ) in the south, at the northern margins of the Tethys, to about $\mathrm{p}-48^{\circ} \mathrm{N}$ at, say, central East Greenland (Smith et al. 1981). The climatic gradient is clearly evident in sedimentary facies. In the south, carbonates dominate, such as lime mudstones and skeletal grainstones, including coarse echinoderm 'breccias'. There are widely developed carbonate platforms and ramps. In the north, carbonates are rare or absent and never rock-forming. The pattern between these extremes is complex. It was evidently determined by an interplay of current patterns and topography, which strongly influenced the distribution of both benthic and nektoplanktonic biotas. Thus, for instance, the eastern Paris Basin, the Jura and what are now the Helvetic Alps $\left(\mathrm{p}-32^{\circ} \mathrm{N}\right)$ saw the build-up of a range of thick bioclastic carbonate platforms in the Bajocian-Bathonian. These shielded the Swabo-Franconian Basin lying behind them from Tethyan influence on its western side, its southern and eastern sides being bounded by the Vindelician and Bohemian massifs. The contrast between the Paris and Swabo-Franconian Basins, lying at similar palaeolatitudes, could therefore hardly be greater, the former abounding in a rich and highly diverse warmwater fossil biota; the latter, a sediment-starved basin with a highly impoverished fauna and almost no carbonates. Further north-west, the warm-water carbonates and their rich biotas, with corals, reached the Cotswolds of England $\left(\mathrm{p}-37^{\circ} \mathrm{N}\right)$, whereas the Middle Jurassic of northern Germany at the same latitude was almost as impoverished as that of Franconia. The furthest north that Tethyan warm-water influences are detected is Scoresby Sund, East Greenland $\left(\mathrm{p}-48^{\circ} \mathrm{N}\right)$, where Bathonian hermatypic corals have been found very close to the transgressive western shoreline of the Viking Straits (Håkansson et al. 1971; Callomon \& Birkelund 1980).

Of immediate concern is the influence of the factors outlined above on the distribution of one group of organisms, the ammonites, for these are the leading guide-fossils whose biostratigraphy provides the primary standard chronostratigraphy over the whole region. The Middle Jurassic saw a strong segregation of the ammonites into three faunal provinces. These occupy successive, broadly latitudinal belts.
The most southerly belt lies along the northern margins of the Tethys, including Iberia (but not the Betic and Subbetic basins of Andalucia), Aquitaine, the southern Paris Basin, the southern Jura, peri-Carpathian Poland and much of the Balkans. It is usually referred to as the Submediterranean Province of the Tethyan Realm. Its ammonite faunas are rich, diverse and characteristic of warm-water, shallow neritic shelf-seas. They differ from those of the Tethyan Province proper mainly in compositions, which are reflections of different bioecological habitats. The true Tethyan faunas are made up predominantly of pelagic groups such as Phylloceras and Lytoceras and are found in the pelagic carbonates of former seamounts and carbonate platforms still preserved, for example, in Andalucia, Sicily, the Apennines, the Venetian and Austrian Alps and the southern Balkans. Their places of entombment were not necessarily in deep water - some of them accumulated cross-bedded oolites - although their living habitats almost certainly were. They do occasionally mingle with the faunas of the shelf-seas, but then invariably as rare stragglers.

The next belt constitutes the Subboreal Province of the Boreal Realm. It extended from the Scottish Highlands in the north $\left(\mathrm{p}-42^{\circ} \mathrm{N}\right)$ across northern Europe (southern England, Normandy, Boulonnais, Germany and the northern Jura, northern and central Poland) into the Moscow-Volga-Donets Basins on the Russian Platform, across the northern Caucasus into trans-Caspian Turkmenistan and the basins of the Amudarya, north of Afghanistan, before now being lost under the Himalayan ranges of the Pamirs. In the Aalenian, Bajocian and Bathonian, the distinction between Submediterranean and Subboreal faunas lies almost wholly in their diversities rather than in their mutually exclusive distributions. The provinces are therefore rarely explicitly differentiated in these Stages and their faunas usually referred to simply as 'European'. The diversity-differentiation is however already clearly discernible in the Aalenian, during which typically Submediterranean families reached Dorset in abundance (Callomon \& Chandler 1994) while being virtually unknown in Swabia and Franconia. The Subboreal Province became clearly differentiated from the Submediterranean Province only in the later Middle Jurassic, the Callovian. It was characterised mainly by two families, the Cardioceratidae and Kosmoceratidae, whose distributions were complementary to those of the Submediterranean Reineckeiidae and Oppeliidae. The boundaries could be sharp, as in going from southern Normandy into Touraine and Poitou, or very diffuse, with much overlap, as in Germany. 
The third, most northerly, belt constitutes the Boreal Province of the Boreal Realm. It existed sporadically already in the Toarcian and Aalenian, but became clearly and strongly differentiated in the late Early and early Late Bajocian. It then persisted into the Cretaceous. It occupied the shelf-seas of the Arctic (there being no positive evidence of the existence at that time of a truly oceanic Arctic Ocean), from the Alaskan North Slope through the Yukon over the Canadian Arctic Archipelago into Svalbard and the whole of the Barents Sea including Franz Josef Land, Novaya Zemlya and the Petshora Basin, the Laptyev Sea and Kheta and Lena Basins in north-central Siberia, and thence into north-eastern Siberia and back to the Bering Straits. During the Middle Jurassic this sea, forming a rough triangle of sides 5000 $\mathrm{km}$, was largely land-locked on two sides, by Laurentia and Eurasia (see map in Callomon 1985, text-fig. 6a). Communication in the early Middle Jurassic with the rest of the world's oceans was possible in only two areas. The first was through a series of gateways into the northern Pacific, between Kolyma in far-eastern Siberia and eastern Alaska (although an anywhere near precise knowledge of where these gateways lay must await a satisfactory plate-tectonic reconstruction of this whole region). The second was the relatively narrow channel of the Viking Straits leading southwards to the epicontinental seas of Europe and thence to the Tethys. A third route opened in the late Middle Jurassic, in the Callovian, when marine transgression from the Petshora across the Russian Platform finally inundated the Moscow-Volga Basins and thence completed the connections with the European epeiric seas from the east.

The connecting route of particular interest here is the one between Laurentia and Fennoscandia along the Viking Straits. The largely landlocked Middle Jurassic seas of the Arctic developed their own endemic faunas of ammonites, which lived and evolved there in almost total isolation from those further south. They did however venture down the Viking Straits as far as the Shetland Islands. Here the seas divided into two channels (Fig. 1). The westerly one passed southwards to the west of Ireland, along the Faroe-Rockall troughs and perhaps others even further west, and gave connections with the western Tethys presumably via the Lusitanian seas west of Iberia. Little detail is so far known about the Middle Jurassic history of these channels. The easterly channel passed to the east of the Shetlands in the general direction of the North Sea and its sediments are preserved and well-documented in the Viking Graben, particularly in the Brent Field (Deegan \& Scull 1977; Underhill \& Partington 1993). The most southerly point from which fully marine Boreal Bathonian sediments with ammonites have so far been described appears to be at Total's well 9/10b-1 (Bruce Field, 5940`N, p$44^{\circ} \mathrm{N}$; Callomon 1979), $170 \mathrm{~km}$ ESE of Lerwick in the Shetlands. Progress further southwards into the North Sea was then blocked by the emergent Central North Sea Dome. Its western non-marine flanking sediments have long been recognised in the various 'Estuarine Series' found in the Aalenian-Bathonian Middle Jurassic of Britain, from Scotland to the eastern Midlands. Marine connections between the northern North Sea and the normal marine seas of Wessex, and the north German and Polish basins were completely cut by a physical barrier. No Middle Jurassic ammonites have been recorded from Denmark, although typical European faunas are again well-represented in the southern Baltic (Stoll 1934). The ammonite faunas of the Boreal and European Provinces were wholly segregated: no region of overlap is known. Both faunas evolved independently and provide the biochronologies on which the standard chronozonations are based. This means, however, that these chronozonations have had to be worked out independently, one standard scale for each Province (see below), and correlations between these provincial scales continue to range from problematic to impossible. Of particular interest here is the fact that the most detailed biochronology of the Boreal Bajocian-Bathonian ammonites anywhere in the Arctic has been that recorded in central East Greenland, through an unusually favourable combination of circumstances (Callomon 1993). It provides currently the chronostratigraphic standard of reference for the whole of the Arctic.

What of the channels to the west of Ireland? No Boreal Middle Jurassic ammonites have so far been found anywhere along their former courses, although this may be due wholly to lack of outcrop or sampling in boreholes. Certainly no ammonites penetrated as far south as the Lusitanian basins $\left(\mathrm{p}-30^{\circ} \mathrm{N}\right)$. Yet that there must have been a fully marine connection is attested by those hermatypic corals found in Milne Land, East Greenland: they could have got there by no other route. The failure of the ammonites to migrate southwards therefore probably reflects an ecological barrier: a case perhaps of inability to migrate against a northerly-flowing warm-water current carrying an inimical food-chain.

Direct marine connections between the Arctic and Europe were restored in the Early Callovian. A second Boreal family of ammonites, the Kosmoceratidae, also with a long pre-Callovian history in the Arctic, suddenly appeared in Europe. But whether the connection was via the Viking Straits or via the Russian Platform 
was until recently not clear: new discoveries now make the latter the more probable (Gulyaev \& Kiselev 1999a, b; Mitta 2000; Mitta \& Starodubtseva 2000). The earliest, a Kepplerites, has been found in the Upper Bathonian of Franconia (Dietl \& Callomon 1988). It resembles a form from the lower Calyx Zone of East Greenland (see below), also of Late Bathonian age. The first horizon with abundant Kepplerites keppleri (Oppel) has been traced from southern England (Upper Cornbrash) via northern and southern Germany to the northern Jura and probably as far as the Caucasus. It marks the base of the Callovian Stage and also has close relatives in East Greenland. It is closely followed by the earliest horizon with abundant Cadoceras of the Cardioceratidae, also traceable from Dorset via Germany to the northern Jura, with now closely related forms all over the Russian Platform (Cadoceras elatmae (Nikitin)). Yet the earliest known ammonites from marine sediments directly overlying non-marine deltaic facies in Scotland came from considerably higher levels, in the early Koenigi Zone on the east coast (Moray Firth) and in the late Koenigi Zone on the west coast (Skye). Furthermore, no Callovian ammonites have been recorded from anywhere in the central North Sea. Indisputably direct marine connections between the Arctic seas and those of Europe via the Viking Straits were however fully reestablished in the Late Callovian (Athleta Zone). The same standard zonation can be applied to sediments from the top of the Lower Callovian upwards in both the Viking Straits as preserved in East Greenland and throughout northern Europe (see below).

\section{Standard zonal chronostratigraphy}

The Middle Jurassic is made up chronostratigraphically of four standard Stages: Aalenian (lowermost, Aalen, south-west Germany), Bajocian (Bayeux, Normandy), Bathonian (Bath, England) and Callovian (uppermost, Kellaways, Wiltshire, England) (Fig. 2). The chronometric ages of its boundaries are not directly very closely determined, but recent reviews (Harland et al. 1990; Odin 1994; Gradstein et al. 1994) are in tolerable agreement in assigning to the Middle Jurassic a duration of $21 \mathrm{Ma}$, i.e. close to a third of the 62-68 Ma of the Jurassic as a whole. Published chronometric ages for individual Stage boundaries are largely based on non-chronometric estimates of their relative durations, such as the number of standard chronostratigraphic Zones or Subzones they (now) contain, and should be treated with corresponding caution (see Pálfy 1995; Pálfy et al. 2000).
The standard Zones and Subzones used here are chronozones defined by their bounding time-planes and are at the lowest two levels (VI and VII) of a hierarchy of successively finer subdivisions of the geological column, of the Jurassic System (III), its Series (IV) and Stages (V) (Callomon 1994, 1995). The observational basis is the biostratigraphy of the most sensitively timediagnostic guide-fossils available, here the ammonites, which serve to characterise the Zones in terms of their contents and to correlate successions. In most cases even finer time-resolutions are possible within a Subzone, based on the recognition in it of more than one distinguishable - in an evolutionary sense - biohorizon, whose number can increase with the growth of knowledge of a highly incomplete geological record (Callomon 1995).

Figure 3 shows standard zonations for the three ammonite biogeographic provinces represented in western Europe. Such zonations grow with time and knowledge. The oldest, going back substantially to Oppel (1856-58) is that covering the Northwest European or Subboreal Province, in which lie most of the outcrops studied during the classical age of geology (column A). It is the best known and most complete and hence provides the primary standard. The zonation used today in the Submediterranean Province is shown alongside it at the left (column B). Its Bathonian part became established in the 1940-50s, its Callovian part a little later. The Boreal zonation shown in the column at the right (C) was wholly unknown before 1959 .

The purpose of diagrams such as these is to represent what are effectively relative time-scales. But as there are no independent ways of estimating the relative durations of the time-periods represented by Zones

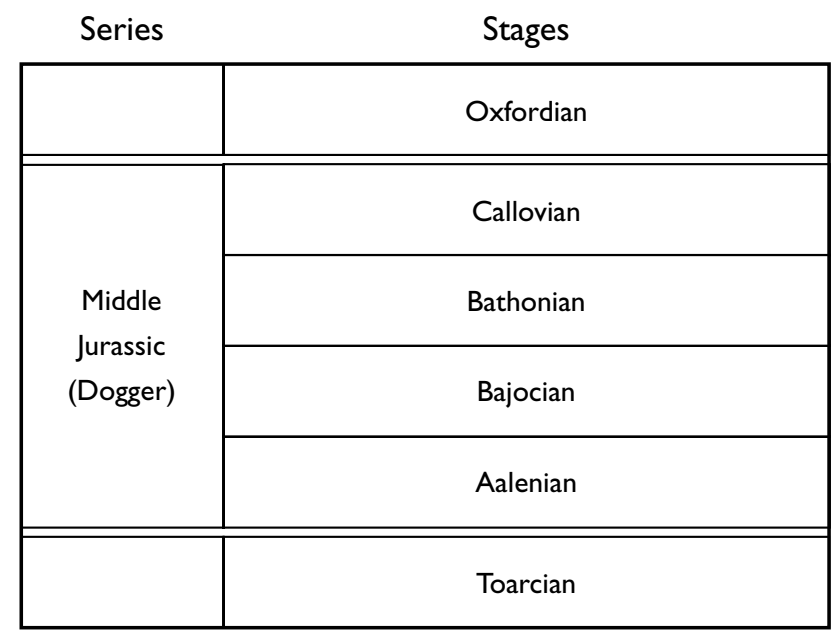

Fig. 2. The primary standard Stages of the Middle Jurassic. 
B

A C

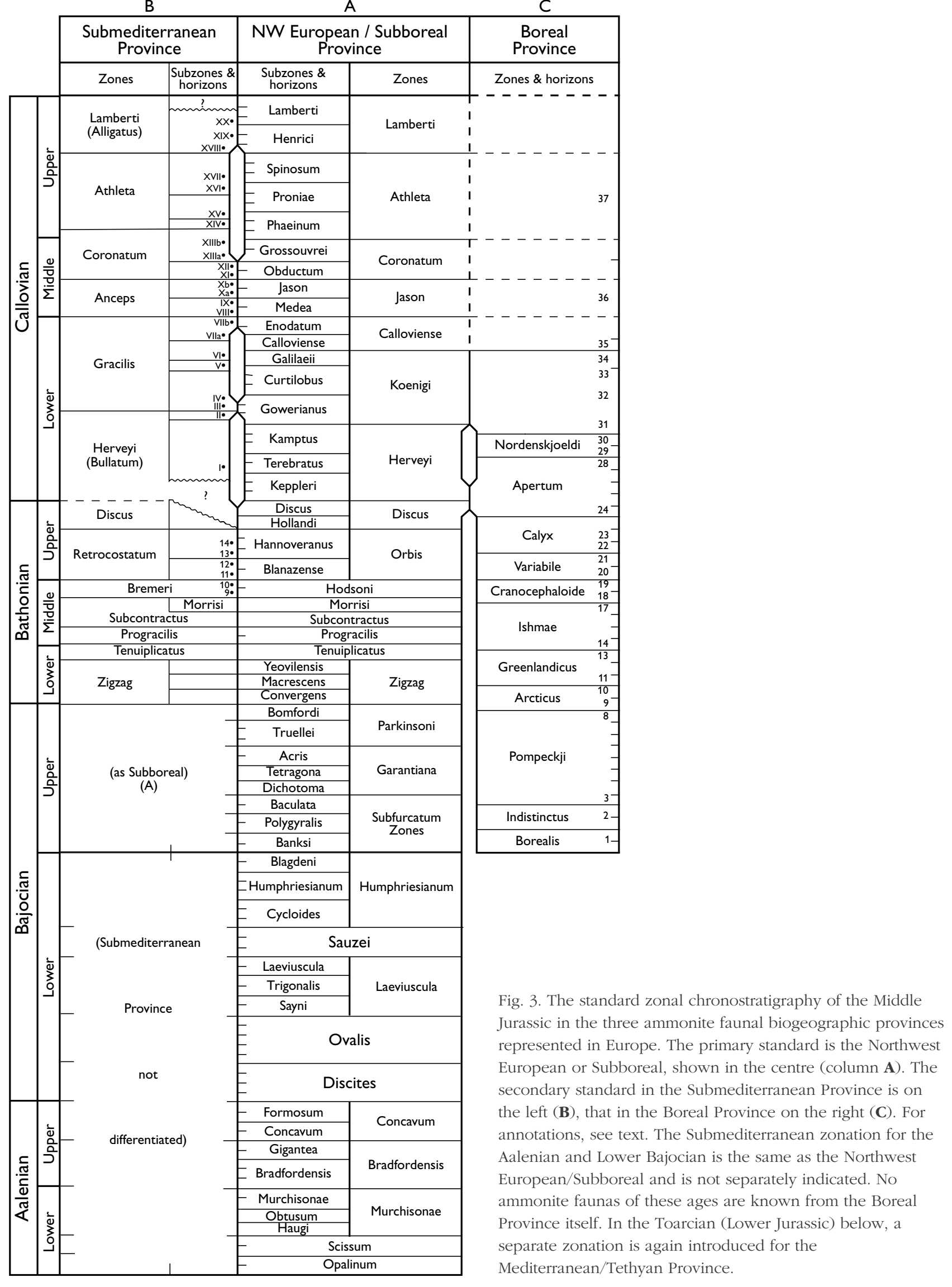


or Subzones, there is no unique or permanent way of drawing the diagrams. The scheme adopted here is to assume that the time-intervals between adjacent distinguishable ammonite biohorizons in the primary standard (A) are equal. As they are the smallest time-intervals at present resolvable by means of ammonites, the errors in this assumption are likely to have the least effect on the implied relative durations of the coarser units, the Zones and Subzones. The known number of such resolvable biohorizons is of course not final either. But as the European standard has been worked on intensively over a long time, it is safe to say that in the Middle Jurassic at least, we are now close to what is achievable in timeresolution by means of ammonites. Taking the estimates of duration of the Middle Jurassic quoted at the beginning, of $21( \pm 4$ ? $) \mathrm{Ma}$, the average time-interval between faunal horizons (115) is $180( \pm 36) \mathrm{ka}$; the average duration of a standard Zone (28) is $750( \pm 150) \mathrm{ka}$.

Correlation between European Subboreal and Submediterranean scales (A-B) is sufficiently close to draw them on the same scale. Correlation between the European and Boreal scales (A-C) even at Zonal level is so imprecisely known that they have to be drawn quite independently. It is however probable that the lowest, Borealis Zone correlates with levels at around the Lower-Upper Bajocian boundary. Such a correlation had been previously postulated on the basis of a chain of correlations via the North American Cordillera (Callomon 1985, p. 64). It has now been confirmed through measurements of the stable isotopic ratio of strontium $\left({ }^{87} \mathrm{Sr} /{ }^{86} \mathrm{Sr}\right.$ ) in belemnites (J.H. Callomon, unpublished data; M. Engkilde, personal communication 1997). Scale $\mathrm{C}$ is therefore also drawn on a faunal-horizon equal-interval assumption, based on the best available ammonite biochronology of East Greenland. The Boreal intervals have, however, been stretched somewhat relative to those of the European standard, to take the Borealis Zone down to the early Upper Bajocian.

\section{A: European Subboreal primary standard}

The names of both Zones and Subzones as currently in use have been written out. To complete their definitions, the bounding time-planes of these standard chronostratigraphic units have to be fixed in boundary stratotype sections. While such definitions have been proposed for many of the Zones and Subzones, none have so far been formally ratified by the International Commission on Stratigraphy, whose aspirations do not currently descend below the level of standard Stages
(Cowie et al. 1986). The lack of such formal definitions appears to have remarkably little consequence in practical day-to-day affairs. The reason has been pointed out repeatedly (Callomon 1995) and is important. It is that rocks are correlated by means of the contents of Zones - what lies between the bounding time-planes - rather than by correlation of the time-planes themselves. The wide variations in the relative time-values and numbers of Subzones in Zones as shown in the column are almost entirely of historical origin, reflecting a compromise between the growth of knowledge (faunal horizons) and a desire to retain some stability in zonal nomenclature. (In the times of Oppel (1856-58) and of Waagen (1867), the number of Zones in what is today's Middle Jurassic was 13; in Arkell's review of 1956 it was 21; here it has grown to 28).

\section{Aalenian-Bajocian}

Based on recent revisions (Callomon \& Chandler 1990; Callomon 1995; Callomon \& Cope 1995).

\section{Bathonian}

The chronostratigraphy of this Stage was one of the last to be worked out in Europe because of exceptionally difficult ammonite biostratigraphy - scattered part-sections with only sparse ammonites. The first comprehensive modern syntheses by Gabilly (1965) and Mangold (1970) were based on the successions in western and eastern France, respectively. A review by Westermann \& Callomon (1988) of its faunal successions was given in terms of 16 faunal horizons, some of which (9-14) are numbered here. Some subsequent refinements in the Upper Bathonian of Swabia were reported by Dietl \& Callomon (1988), and a discrepancy between the Middle and Upper Bathonian boundaries as drawn in the Northwest European and Submediterranean classifications was resolved by Mangold (1988). The most recent reviews, by Callomon \& Cope (1995, p.73) and Mangold \& Rioult (1997), differ in some details of nomenclature but retain essentially the same biostratigraphic basis of faunal horizons. Thus horizon 11, of Procerites quercinus, is elevated into a Quercinus Subzone of the Northwest European Hodsoni Zone, thereby raising the base of the Orbis Zone by one horizon; and the Convergens and Yeovilensis Subzones of the Zigzag Zone are given separate names in the Submediterranean Province. The historically-conditioned difference between 
the numbers of faunal horizons in the Lower-Middle and Upper Bathonian respectively is here particularly marked.

\section{Callovian}

Much new information in recent years has greatly amplified our knowledge of the Lower and Upper parts of the Stage. The former was revised by Callomon et al. (1988) and Page (1989), the latter by Dietl (1994 and unpublished data, based on excavations in Swabia) and Callomon \& Cope (1995). The Herveyi Zone is the former Macrocephalus Zone renamed, after it was discovered that the type-horizon of the index Macrocephalites macrocephalus (Schlotheim) did not in fact lie in its eponymous Zone (Callomon et al. 1992). A similar change of index will have to be made for the Spinosum Subzone of the Athleta Zone, because the type-horizon of Kosmoceras spinosum (J. de C. Sowerby) is now known to lie in the Lamberti Zone. Only the Coronatum Zone remains in need of a modern revision. The Middle-Upper Callovian boundary as reproduced here was defined in terms of the phyletic transients of the lineage of Kosmoceras in England (Callomon 1964, 1968) and not on the first appearance of Peltoceras, which came in a little later. The upper boundary of the Callovian Stage, and hence the Middle-Upper Jurassic boundary, has always been taken biostratigraphically to lie between the highest known faunal horizon of the Lamberti Zone, that of Quenstedtoceras paucicostatum Lange, and the lowest horizon of the Oxfordian Mariae Zone, that of $Q$. woodhamense Arkell. It was usually easy to recognise because over large parts of Northwest Europe it is marked by a non-sequence. The discovery of expanded sequences across the boundary, e.g. in Dorset and southern France, has made the final choice of stratotype section a matter of current debate.

\section{B: Submediterranean secondary standard}

\section{Aalenian-Bajocian}

The Northwest European zonation is applicable and no separate scheme has been introduced.

\section{Bathonian}

Also reviewed by Westerman \& Callomon (1988) and Mangold \& Rioult (1997). The Northwest European zonation is used for the Lower and all but the topmost Middle Bathonian. Differentiation became marked only in the Upper Bathonian. The Submediterranean succession was worked out mainly in France, particularly in Poitou (Gabilly 1965), the southern Paris Basin and the southern Jura (Mangold 1970). There its uppermost part appears to be marked also by a widespread faunal or stratigraphical non-sequence, so that the BathonianCallovian boundary was until recently not clearly characterised (see below).

\section{Callovian}

Based predominantly on the faunal succession in western France worked out by Cariou (1980, 1984). His labelling of faunal horizons (I-XX) has been included here, although the names of the Subzones, many of which contain only a single faunal horizon, have been omitted. Both bottom and top of the succession are marked by regionally widespread gaps. Since Figure 3 was drawn, however, a newly discovered section at Buffevent, near Niort in Poitou, shows an expanded succession that spans the Bathonian-Callovian boundary (B. Balusseau, P. Branger and E. Cariou, personal communications 2000). Most particularly, one of its beds has yielded Kepplerites keppleri, characteristic of the basal faunal horizon of the Callovian Stage by definition (Callomon \& Dietl 2000). The bases of the Callovian Stages in both primary NW European (A) and secondary Submediterranean (B) classifications can therefore be taken to coincide exactly.

There remain some nomenclatural inconsistencies to be resolved, in that while some of the Zones, e.g. Gracilis and Anceps, are named after distinct Submediterranean indices, others, such as Coronatum and Athleta, share their names with their counterparts in the primary standard (A). Yet these Zones are independently defined and are of slightly different extents. The Submediterranean Athleta Zone, for instance, has been chosen to begin at the first appearance of Peltoceras in the Hecticoceras trezeense horizon, XV, which lies at a level near the top of the Phaeinum Subzone of the primary Athleta Zone. The lowest Callovian Zone had for a long time been given a separate name and identity, the Bullatum Zone, as neither its base nor its top could be closely correlated with the primary standard. Precise correlation of its base has now been achieved (see above) and so the main obstacle overcome. It has therefore been entered in Figure 3 also under the name of the primary index as Herveyi Zone (olim Macro- 
cephalus). As its top, the base of the overlying Gracilis Zone, continues to be independently defined, it may be more appropriate, however, to continue to follow French usage (Thierry et al. 1997) and to retain the Bullatum Zone in the Submediterranean classification. An analogous alternative for the name of the top Callovian Zone in the Submediterranean Province, instead of Lamberti, would be [Perisphinctes] Alligatus Zone.

\section{C: Boreal secondary standard}

This was recently reviewed by Callomon (1993), based on the ammonite succession in East Greenland. Almost no ammonite faunas of Aalenian - Early Bajocian ages have been recorded anywhere in the European Arctic, and in much of the region the record of this period is marked either by stratigraphical gaps, or unfossiliferous or non-marine deposits (Smelror 1994). In East Greenland, the youngest ammonite faunas known from below the Borealis Zone are of Early Toarcian age (Pseudolioceras lythense, Bifrons Zone). In Svalbard and the Barents Shelf, the same is probably true, for claims to have recognized earliest Aalenian ammonites, associated with Toarcian forms, in a remanié conglomerate, the Brentskardhaugen Bed (Wierzbowski et al. 1981), are based almost certainly on misidentifications as close Aalenian homoeomorphs of the older Toarcian species.

The Borealis Zone is clearly recognisable throughout the whole of the Arctic and is now known to correlate with the lower Upper Bajocian of Europe or levels even a little older (see general discussion above). Thereafter, the faunal horizons are numbered 1-35 up to the top of the Lower Callovian, as in Callomon (1993), with a few subsequent additions based on recent unpublished field observations. They form the basis of the Boreal zonation. Zones have so far not been subdivided, and their different relative durations also reflect the historical evolution of knowledge. In the Middle and Upper Callovian of East Greenland, ammonites are so sparse (although the succession is thick) that they contribute nothing further to standard chronostratigraphy. Elsewhere, for example in arctic Russia and Siberia, the Upper Callovian is divided into a lower Zone of Longaeviceras keyserlingi and an upper Zone of Eboraciceras subordinarium (Meledina 1977), but the ammonite biostratigraphy is so fragmentary that they have not been included here.

\section{Conclusion}

The Middle Jurassic of those parts of Europe under discussion in this volume encompasses a highly diverse range of tectonic, sedimentary and palaeobiotic developments. To unravel their evolution successfully calls for the closest possible time-control of the rocks: of time-correlations over distances and of time-resolution more locally. Fortunately, such time-control is provided by an abundance of good guide-fossils, the ammonites, whose biostratigraphy has given us a chronostratigraphic calendar of unrivalled finesse and hence, conversely, the clocks for dating individual rocks with great precision. The construction of the calendar has taken much effort over many years in many countries and the calendar that has emerged may seem complicated. But the rewards justify the effort needed to master these complexities.

\section{Acknowledgement}

This review was written during the tenure of a Leverhulme Emeritus Fellowship, which is gratefully acknowledged.

\section{References}

Arkell, W.J. 1956: Jurassic geology of the World, 806 pp. Edinburgh, London: Oliver \& Boyd.

Callomon, J.H. 1964: Notes on the Callovian and Oxfordian Stages. In: Maubeuge, P.L. (ed.): Colloque du Jurassique à Luxembourg 1962, 269-291. Luxembourg: Publication de l'Institut GrandDucal.

Callomon, J.H. 1968: The Kellaways Beds and the Oxford Clay. In: Sylvester-Bradley, P.C. \& Ford, T.D. (eds): The geology of the East Midlands, 264-290. Leicester, UK: Leicester University Press.

Callomon, J.H. 1979: Marine Boreal Bathonian fossils from the northern North Sea and their palaeogeographical significance. Proceedings of the Geologists' Association (London) 90 , 163-169.

Callomon, J.H. 1985: The evolution of the Jurassic ammonite family Cardioceratidae. In: Cope, J.C.W. \& Skelton, P.W. (eds) Evolutionary case histories from the fossil record. Special Papers in Palaeontology 33, 49-90. London: Palaeontological Association.

Callomon, J.H. 1993: The ammonite succession in the Middle Jurassic of East Greenland. Bulletin of the Geological Society of Denmark 40, 83-113.

Callomon, J.H. 1994: Jurassic ammonite biochronology of Greenland and the Arctic. Bulletin of the Geological Society of Denmark 41, 128-137. 
Callomon, J.H. 1995: Time from fossils: S.S. Buckman and Jurassic high-resolution geochronology. In: Le Bas, M. (ed.): Milestones in Geology. Geological Society Memoir (London) 16, 127-150.

Callomon, J.H. \& Birkelund, T. 1980: The Jurassic transgression and the mid-Late Jurassic succession in Milne Land, central East Greenland. Geological Magazine 117, 211-226.

Callomon, J.H. \& Chandler, R.B. 1990: A review of the ammonite horizons of the Aalenian - Lower Bajocian Stages in the Middle Jurassic of southern England. In: Cresta, S. \& Pavia, G. (eds): Atti del meeting sulla stratigrafia del Baiociano. Memorie descrittive della Carta Geologica d'Italia 40, 85-111.

Callomon, J.H. \& Chandler, R.B. 1994: Some early Middle Jurassic ammonites of Tethyan affinities from the Aalenian of southern England. In: Pallini, G. (ed.): Proceedings of the 3rd Pergola International Symposium 'Fossili, Evoluzione, Ambiente'. Palaeopelagos Special Publication 1, 17-40. Rome: Università 'La Sapienza'.

Callomon, J.H. \& Cope, J.C.W. 1995: The Jurassic geology of Dorset. In: Taylor, P.D. (ed.): Field geology of the British Jurassic, 51-103. London: Geological Society.

Callomon, J.H. \& Dietl, G. 2000: On the proposed Basal Boundary Stratotype (GSSP) of the Middle Jurassic Callovian Stage. In: Hall, R.L. \& Smith, P.L. (eds): Advances in Jurassic Research 2000. Proceedings of the 5th International Symposium on the Jurassic System. GeoResearch Forum 6, 41-54.

Callomon, J.H., Dietl, G. \& Page, K.N. 1988: On the ammonite faunal horizons and standard zonations of the Lower Callovian Stage in Europe. In: Rocha, R.B. \& Soares, A.F. (eds): 2nd International Symposium on Jurassic stratigraphy (Lisbon 1987) 1, 359-376. Lisbon: Universidade Nova de Lisboa.

Callomon, J.H., Dietl, G. \& Niederhöfer, H.-J. 1992: On the true stratigraphic position of Macrocephalites macrocephalus (Schlotheim 1813) and the nomenclature of the standard Middle Jurassic 'Macrocephalus Zone'. Stuttgarter Beiträge zur Naturkunde B 185, 65 pp.

Cariou, E. 1980: L'étage Callovien dans le centre-ouest de la France. Première partie: stratigraphie et paléogéographie. Thèse, Docteur ès Sciences naturelles, Université de Poitiers, U.E.R. Sciences Fondamentales et Appliquées 325, 110 pp.

Cariou, E. 1984: Biostratigraphic subdivision of the Callovian stage in the Subtethyan province of ammonites, correlations with the Subboreal zonal scheme. In: Michelsen, O. \& Zeiss, A. (eds): International Symposium on Jurassic stratigraphy (Erlangen 1984) 2, 315-326. Copenhagen: Geological Survey of Denmark.

Cowie, J.W., Ziegler, W., Boucot, A.J., Bassett, M.G. \& Remane, J. 1986: Guidelines and statutes of the International Commission on Stratigraphy (ICS). Courier Forschungsinstitut Senckenberg 83, 14 pp.

Deegan, C.E. \& Scull, B.J. 1977: A standard lithostratigraphic nomenclature for the central and northern North Sea. Institute of Geological Sciences Report 77/25, 36 pp. London: Her Majesty's Stationery Office.

Dietl, G. 1994: Der punctulatum-Horizont - ein neuer Ammoniten faunen-Horizont aus dem schwäbischen Ornaten-Ton (OberCallovium, Mittlerer Jura). Geologische Blätter von NO-Bayern 43, 15-32.
Dietl, G. \& Callomon, J.H. 1988: Der Orbis-Oolith (OberBathonium, Mittl. Jura) von Sengenthal/Opf., Fränk. Alb, und seine Bedeutung für die Korrelation und Gliederung der OrbisZone. Stuttgarter Beiträge zur Naturkunde B 142, 31 pp.

Gabilly, J. 1965: Le Jurassique inférieur et moyen sur le littoral vendéen. Travaux de l'Institut de Géologie et Anthropologie préhistorique de la Faculté des Sciences de Poitiers 5, 67-107.

Gradstein, F.M., Agterberg, F.P., Ogg, J.G., Hardenbol, J., van Veen, P., Thierry, J. \& Huang, Z. 1994: A Mesozoic time scale. Journal of Geophysical Research 99, 24051-24074.

Gulyaev, D.B. \& Kiselev, D.N. 1999a: On marine Boreal Upper Bathonian on the central Russian Platform. Doklady Akademii Nauk 367, 95-98 (in Russian).

Gulyaev, D.B. \& Kiselev, D.N. 1999b: Boreal marine Upper Bathonian in Middle Povolzhia [Middle Volga] (ammonites and stratigraphy). Stratigrafiya, Geologicheskiya Korrelatsiya 7, 79-94 (in Russian).

Håkansson, E., Birkelund, T., Heinberg, C. \& Willumsen, P. 1971: Preliminary results of mapping the Upper Jurassic and Lower Cretaceous sediments of Milne Land. Rapport Grønlands Geologiske Undersøgelse 37, 32-41.

Hallam, A. 1988: A reevaluation of Jurassic eustasy in the light of new data and the revised Exxon curve. In: Wilgus, C.K. et al. (eds): Sea-level changes - an integrated approach. Society of Economic Paleontologists and Mineralogists Special Publication 42, 261-273.

Harland, W.B., Armstrong, R.L., Cox, A.V., Craig, L.E., Smith, A.G. \& Smith, D.G. 1990: A geologic time scale 1989, 263 pp. Cambridge: Cambridge University Press.

Mangold, C. 1970: Stratigraphie des étages Bathonien et Callovien du Jura méridional. Documents du Laboratoire de Géologie de la Faculté des Sciences, Lyon 41(1), 376 pp.

Mangold, C. 1988: Reports of the Working Groups: Bajocian/ Bathonian boundary and Bathonian. In: Rocha, R.B. \& Soares, A.F. (eds): 2nd International Symposium on Jurassic stratigraphy (Lisbon 1987) 1, 17-18. Lisbon: Universidade Nova de Lisboa.

Mangold, C. \& Rioult, M. 1997: 7. Bathonien. In: Cariou, E. \& Hantzpergue, P. (eds): Biostratigraphie du Jurassique ouestEuropéen et méditerranéen. Bulletin du Centre de Recherches Elf Exploration Production Mémoire 17, 55-62.

Meledina, S.V. 1977: Ammonites and stratigraphic zoning of the Callovian in Siberia. Trudy Instituta Geologii i Geofiziki (Novosibirsk) 356, 290 pp. (in Russian).

Mitta, V.V. 2000: Ammonites and biostratigraphy of the Lower Callovian of the Russian Platform. Byulletin Kollektsionnogo Fonda VNIGNI, Moskva 3, 144 pp. (in Russian with German abstract).

Mitta, V.V. \& Starodubtseva, I.A. 2000: W.A. Stchirowsky and the study of the Mesozoic in the Alatyr-Kurmysh area (basin of the Middle Volga). Vernadsky Museum Novitates, Moscow 5, 20 pp. (in Russian with English abstract).

Odin, G.S. 1994: Geological time scale (1994). Comptes Rendus de l'Académie des Sciences (Paris) Série 2 318, 59-71.

Oppel, A. 1856-58: Die Juraformation Englands, Frankreichs und des südwestlichen Deutschlands, nach ihren einzelnen Gliedern eingeteilt und verglichen, 857 pp. Stuttgart: Ebner \& Seubert. 
Page, K.N. 1989: A stratigraphical revision for the English Lower Callovian. Proceedings of the Geologists' Association (London) 100, 363-382.

Pálfy, J. 1995: Development of the Jurassic geochronologic scale. Hantkeniana, Budapest 1, 13-25.

Pálfy, J., Smith, P.L. \& Mortensen, J.K. 2000: A U-Pb and ${ }^{40} \mathrm{Ar} /{ }^{39} \mathrm{Ar}$ time scale for the Jurassic. Canadian Journal of Earth Sciences 37, 923-944.

Richards, P.C., Lott, G.K., Johnson, H., Knox, R.W.O’B. \& Riding, J.B. 1993: Jurassic of the central and northern North Sea. In: Knox, R.W.O'B. \& Cordey, W.G. (eds): Lithostratigraphic nomenclature of the UK North Sea 3, 219 pp. Nottingham: British Geological Survey.

Sahagian, D., Pinous, O., Olferiev, A. \& Zakharov, V. 1996: Eustatic curve for the Middle Jurassic - Cretaceous based on Russian Platform and Siberian stratigraphy: zonal resolution. American Association of Petroleum Geologists Bulletin 80, 1433-1458.

Smelror, M. 1994: Jurassic stratigraphy of the western Barents Sea region: a review. In: Cariou, E. \& Hantzpergue, P. (eds): 3ème Symposium International de stratigraphie du Jurassique (Poitiers 1991). Geobios Mémoire Spécial 17, 441-452.

Smith, A.G., Hurley, A.M. \& Briden, J.C. 1981: Phanerozoic paleocontinental world maps, 102 pp. Cambridge: Cambridge University Press.

Stoll, E. 1934: Die Brachiopoden und Mollusken der pommerschen Doggergeschiebe. Abhandlungen aus dem geologisch-palaeontologischen Institut der Universität Greifswald 13, 62 pp.

Thierry, J., Cariou, E., Elmi, S., Mangold, C., Marchand, D. \& Rioult, M. 1997: 8. Callovien. In: Cariou, E. \& Hantzpergue, P. (eds): Biostratigraphie du Jurassique ouest-européen et médi- terranéen: zonations parallèles et distribution des invertébrés et microfossiles. Bulletin du Centre de Recherches Elf Exploration Production Mémoire 17, 63-78.

Underhill, J.R. \& Partington, M.A. 1993: Jurassic thermal doming and deflation in the North Sea: implications of the sequence stratigraphic evidence. In: Parker, J.R. (ed.): Petroleum geology of Northwest Europe: proceedings of the 4th conference, 337-345. London: Geological Society.

Underhill, J.R. \& Partington, M.A. 1994: Use of genetic sequence stratigraphy in defining and determining a regional tectonic control on the "Mid-Cimmerian Unconformity" - implications for North Sea basin development and the global sea-level chart. In: Weimer, P. \& Posamentier, H.W. (eds): Siliciclastic sequence stratigraphy: recent developments and applications. American Association of Petroleum Geologists Memoir 58, 449-484.

Waagen, W. 1867: Über die Zone des Ammonites sowerbyi. Benecke's Geognostisch-paläontologische Beiträge 1, 507-668.

Westermann, G.E.G. \& Callomon, J.H. 1988: The Macrocephalitinae and associated Bathonian and Early Callovian (Jurassic) ammonoids of the Sula Islands and New Guinea. Palaeontographica A 203, 1-90.

Wierzbowski, A., Kulicki, C. \& Pugaczewska, H. 1981: Fauna and stratigraphy of the uppermost Triassic and the Toarcian and Aalenian deposits in the Sassenfjorden, Spitsbergen. Acta Palaeontologica Polonica 26, 195-241.

Ziegler, P.A. 1982: Geological atlas of western and central Europe, 130 pp. The Hague: Elsevier for Shell Internationale Petroleum Maatschappij. 
